\title{
Effect of temperature on the interaction between Chrysoperla externa (Neuroptera: Chrysopidae) and Sipha flava (Hemiptera: Aphididae)
}

\author{
Simone A. OliVEIRA ${ }^{1}$, Alexander M. AUAD ${ }^{2}$, Brígida SOUZA ${ }^{1}$, Daniela M. SilVA² and Caio A. CARVAlHO ${ }^{2}$ \\ ${ }^{1}$ Departamento de Entomologia, Universidade Federal de Lavras, Campus Universitário, Caixa Postal 3037, \\ Cep 37200-000, Lavras - MG, Brazil; e-mail: sibiojf@yahoo.com.br \\ ${ }^{2}$ Empresa Brasileira de Pesquisa Agropecuária - Embrapa Gado de Leite, Rua Eugênio do Nascimento 610, Dom Bosco, \\ Juiz de Fora - MG, Brazil
}

Key words. Neuroptera, Chrysopidae, Chrysoperla externa, Hemiptera, Aphididae, Sipha flava, aphids, green lacewing, predator, biological control

\begin{abstract}
This paper examines some biological aspects and the predatory capacity of Chrysoperla externa fed nymphs of Sipha flava and reared at different temperatures. Recently hatched larvae were placed individually in Petri dishes, fed ad libitum with $S$. flava and reared at either $12,16,20,24,28$ or $32 \pm 1{ }^{\circ} \mathrm{C}$, a RH of $70 \pm 10 \%$ and a 12 -h photophase. The experiment was fully randomized with 30 replicates of each treatment. The duration and survival in each instar, and larval and pupal stages (pre-pupa + pupa) were analyzed. To determine the predatory capacity of larvae they were each provided daily with three-day-old nymphs of the aphid, in a number greater than they could consume. Ninety $C$. externa larvae were kept individually in Petri dishes at $24 \pm 1^{\circ} \mathrm{C}$, and their daily consumption recorded during development. Temperature influenced the rate of larval and pupal development. There was a decrease in the duration of development with increase in temperature. Regression analyses, based on quadratic equations, were used to describe the effect of temperature on the duration of development in the different instars of C. externa. This revealed that the base temperature increased as the larvae developed towards the adult phase. The survival of larvae in the first and second instars was similar at $12,16,20,24,28$ and $32^{\circ} \mathrm{C}$ but none of the third instar larvae completed their development at $12^{\circ} \mathrm{C}$ and $32^{\circ} \mathrm{C}$. The average daily and total consumption of aphids by third instar larvae was about 48 times greater than that of first instar larvae. The larvae ate an average of 10, 37 and 479 aphids in the first, second and third instars, respectively.
\end{abstract}

\section{INTRODUCTION}

Many species of aphids are serious pests of various crops, among them Sipha flava (Forbes) (Hemiptera: Aphididae), known as the "pulgão-amarelo" in Portuguese and yellow sugarcane aphid in English. In addition to sugarcane it is recorded from a number of cereal crops (Blackman \& Eastop, 2000) and other grasses (MedinaGaud et al., 1965; Kindler \& Dalrymple, 1999; Blackman \& Eastop, 2000). It mainly attacks the leaves (Holman, 1974), where the damage is shown by red spots (Webster, 1990; Costa-Arbulú et al., 2001). Because $S$. flava it is an emerging pest, particularly in greenhouses, more research is needed to reduce the losses caused by this aphid.

One way of reducing populations of insect pests is biological control. Various lacewing species (Neuroptera: Chrysopidae) have attracted the attention of researchers due to the voracity and hunting capacity of their larvae, as well as their high reproductive potential, ability to adapt to laboratory conditions and tolerance of some phytosanitary products (Murata et al., 2006; Silva et al., 2006). In Brazil, one of the most-studied species is Chrysoperla externa (Hagen), particularly because of its widespread occurrence on various crops and its ability to feed on a wide range of prey species.

The efficiency of natural enemies is affected by environmental conditions, mainly temperature (Samson \& Blood, 1979). Similar to other insects the speed of development increases with increase in temperature also in lacewings (Canard \& Principi, 1984; Maia et al., 2000; Fonseca et al., 2001).

Previous studies in Brazil have assessed the use of lacewings in integrated pest management programs of aphids on grasses, such as Schizaphis graminum (Rondani) on sorghum (Fonseca et al., 2001; Figueira et al., 2002) and Rhopalosiphum maidis (Fitch) on corn (Maia et al., 2004). These studies have shown that this predator can develop at temperatures ranging from $12^{\circ} \mathrm{C}$ to $30^{\circ} \mathrm{C}$ and that temperature affects the survival of the latter development stages and the feeding rate. These biological parameters can vary depending on the prey species offered. These findings help in the formulation of pest management measures. But there is no study in which $S$. flava is the prey, which according to Oliveira et al. (2009) is the main aphid species on elephant grass.

Knowledge of the biological parameters and predatory capacity of $C$. externa fed with $S$. flava, over a temperature range of $12^{\circ} \mathrm{C}$ to $32^{\circ} \mathrm{C}$ - the most suited for this aphid's development according to Oliveira et al. (2009) will help in predicting the synchronization of the occurrence of the predator and prey and the effect of the predator on the population density of this aphid in the field.

The objective of this work was to study the effect of temperature on development of $C$. externa and the number of $S$. flava consumed. 


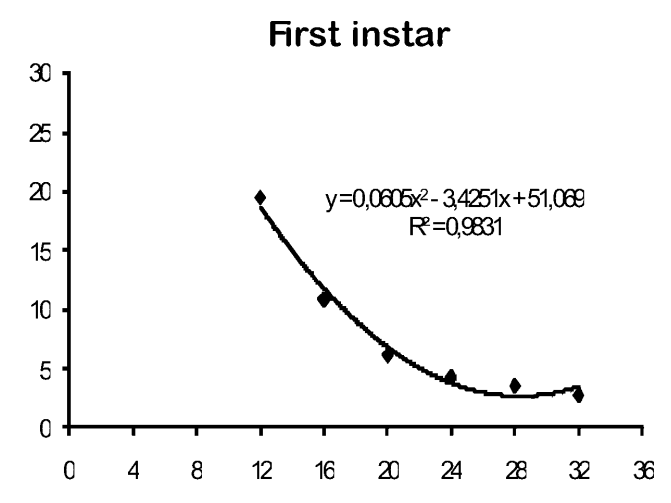

Third instar

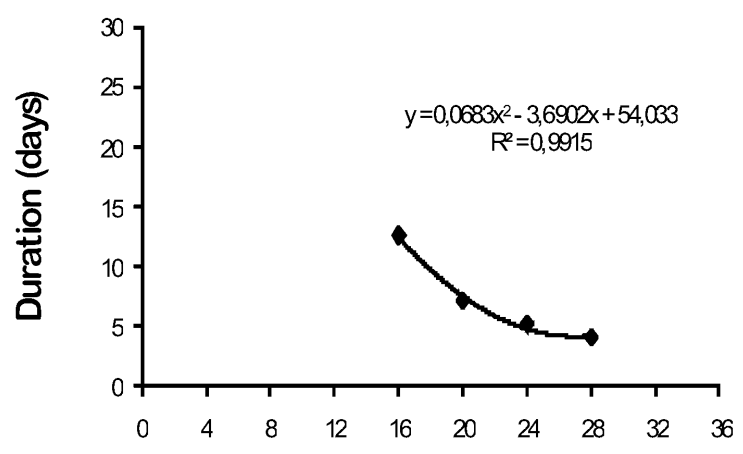

Second instar

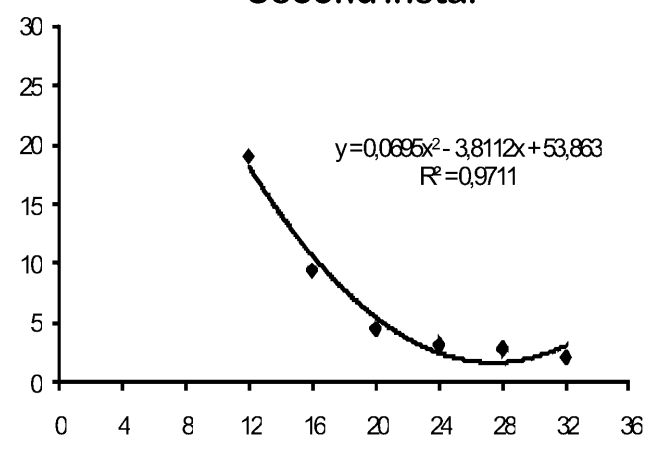

Larval stage

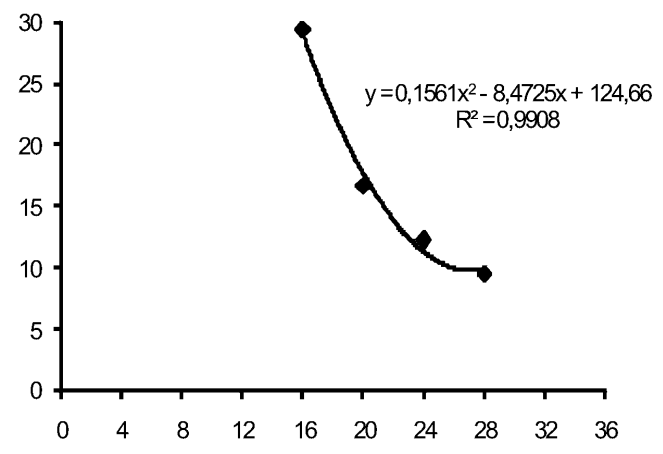

Pupal stage

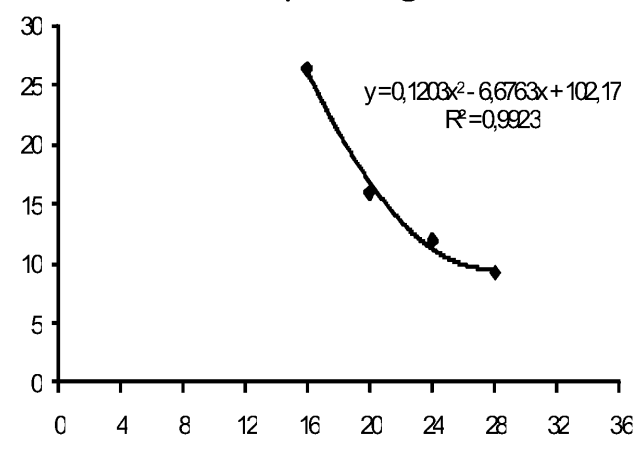

Temperature $\left({ }^{\circ} \mathrm{C}\right)$

Fig. 1. Regression curves fitted to the average duration of development of the first, second and third instar larvae, total larval development and pupal stage of Chrysoperla externa fed Sipha flava and reared at 12, 16, 20, 24, 28 and $32^{\circ} \mathrm{C}$.

\section{MATERIAL AND METHODS}

C. externa eggs were obtained from the Entomology Laboratory of the Federal University of Lavras, Minas Gerais, Brazil. C. externa larvae that had recently hatched from eggs laid by adults from a culture that had been maintained in the laboratory for several generations (generation F3) were individually placed in 5-cm diameter Petri dishes containing a piece of a blade of elephant grass, Pennissetum purpureum Schum, placed on a layer of Agar (1\%) and covered with filter paper that had been perforated with a pin for aeration. The pieces of grass were changed every three days. The dishes were placed simultaneously inclimate controlled chambers maintained at constant temperatures of $12,16,20,24,28$ or $32 \pm 1{ }^{\circ} \mathrm{C}, \mathrm{RH} 70 \pm 10 \%$ and photophase of $12 \mathrm{~h}$. There were 30 replicates of each treatment and each larva - which constituted a replicate - was fed S. flava nymphs ad libitum.
To evaluate the influence of temperature on the development period of each instar and the larval and pupal stages (pre-pupa and pupa) of C. externa, the results were analyzed using regression analysis. The lower threshold temperature and thermal constant were estimated by fitting a hyperbolic equation to the results (Bean, 1961).

To assess the predatory capacity of $C$. externa, adult aphids raised in the laboratory were placed in $5-\mathrm{cm}$ diameter Petri dishes containing pieces of elephant grass on a layer of agar (1\%). After $24 \mathrm{~h}$ the adult aphids were removed, leaving only the nymphs that after three days were offered to the predators in a number greater than they could consume in $24 \mathrm{~h}$. The purpose of offering aphids of uniform age was to standardize their size. The average number of prey consumed daily by $C$. externa larvae in the different instars was determined by a preliminary test consisting of 10 replicates. 
TABLE 1. Regression equations, determination coefficients $\left(\mathrm{R}^{2}\right)$, lower threshold temperature (LTT) and thermal constants (K) (degree-days) for the different instars and immature development (larval and pupal) of Chrysoperla externa fed on Sipha flava. RH $70 \pm 10 \%, 12-\mathrm{h}$ photophase.

\begin{tabular}{lcccc}
\hline Instar/Stage & Equations & $\mathrm{R}^{2}$ & LTT $\left({ }^{\circ} \mathrm{C}\right)$ & $\mathrm{K}(\mathrm{DD})$ \\
\hline First instar & $-0.1455+0.0155 \mathrm{x}$ & 0.99 & 9.4 & 64.5 \\
Second instar & $-0.1985+0.0203 \mathrm{x}$ & 0.98 & 9.8 & 49.3 \\
Third instar & $-0.1583+0.0147 \mathrm{x}$ & 0.99 & 10.8 & 68.0 \\
Larval stages & $-0.0714+0.0069 \mathrm{x}$ & 0.91 & 10.7 & 144.9 \\
Pupal stage & $-0.0538+0.0058 \mathrm{x}$ & 0.99 & 9.3 & 172.0 \\
\hline
\end{tabular}

Larvae were placed individually in the 5-cm diameter Petri dishes, which were then enclosed in PVC film perforated for aeration and kept in a climate-controlled chamber at $24 \pm 1^{\circ} \mathrm{C}$, the temperature at which the values of feeding of $C$. externa recorded in this study were greatest. A total of 30 larvae were used and their daily and total predatory capacities recorded. The results were analyzed using regression analysis.

\section{RESULTS AND DISCUSSION}

\section{Duration of the immature stages of Chrysoperla externa}

Over the range $16-28^{\circ} \mathrm{C}$, the average duration of each instar and the total larval stage was shorter at high than at low temperatures, following the general rules valid for all poikilotherms animals. The regression analyses of the relationships between temperature and the duration of the different development stages expressed in terms of quadratic polynomials gave the best fitting curves (Fig. 1). Fonseca et al. (2001) studied the same lacewing, fed with $S$. graminum and reported the same results.

The larvae of $C$. externa that were reared at $12^{\circ} \mathrm{C}$ and $32^{\circ} \mathrm{C}$ did not complete the third instar. In general, the lacewings spent longer in the third than in the previous two instars irrespective of the temperature.

Because of the high mortality during the third instar at the two extreme temperatures $\left(12^{\circ} \mathrm{C}\right.$ and $\left.32^{\circ} \mathrm{C}\right)$ it was not possible to determine duration of development of this instar at these temperatures. Cardoso \& Lazzari (2003), studying the development of the larvae of this lacewing from the region of Curitiba in the southern state of Paraná, fed on Cinara spp. (Hemiptera: Aphididae), record an average larval duration of 59.5 days at $15^{\circ} \mathrm{C}$, twice the duration recorded in the present study at nearly the same temperature $\left(16^{\circ} \mathrm{C}\right.$ and 29.4 days on average). These results suggest that most probably the type of prey but also the predator's geographic origin can affect the duration of development of lacewings, even when they are reared at similar temperatures. This agrees with the findings by Smith (1922).

Rearing $S$. flava at different temperatures indicate it can complete development at $20^{\circ} \mathrm{C}$ and $24^{\circ} \mathrm{C}$ (Oliveira et al., 2009). Thus $C$. externa is potentially a natural control agent of this aphid pest, since the range of temperatures over which both these species can complete their development overlap.

Also the length of the pupal stage decreased with increase in temperature, from 26.4 days at $16^{\circ} \mathrm{C}$ to 9.3 days at $28^{\circ} \mathrm{C}$. The larvae that developed at $12^{\circ} \mathrm{C}$ and $32^{\circ} \mathrm{C}$ did not reach the pupal stage. A shorter duration (7.4
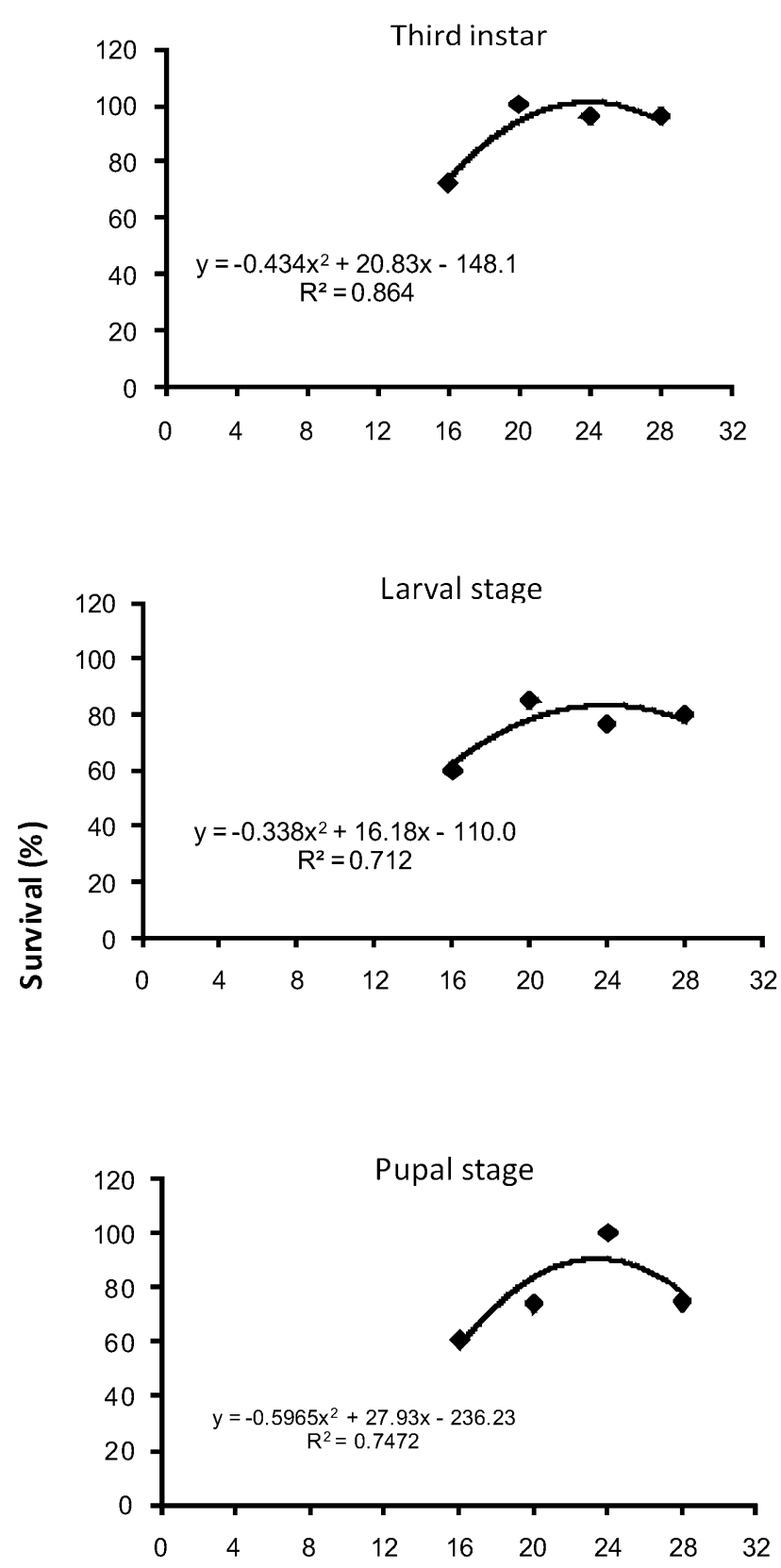

Temperature $\left({ }^{\circ} \mathrm{C}\right)$

Fig. 2. Regression curves fitted to the average percentage survival of third instar larvae, larval stage and pupae of Chrysoperla externa fed Sipha flava and reared at 16, 20, 24 and $28^{\circ} \mathrm{C}$. 


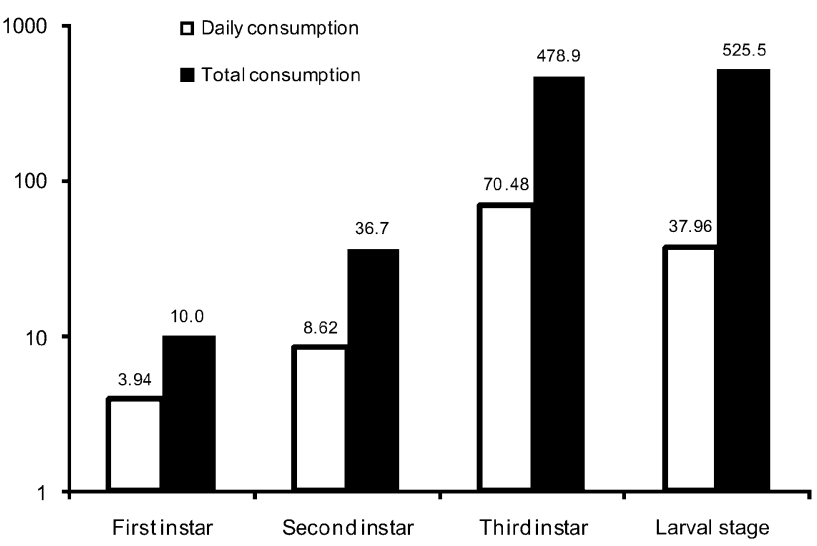

Fig. 3. Average daily and total consumption of Sipha flava nymphs by first, second and third instar larvae, and all of the larval stages of Chrysoperla externa reared at $24 \pm 1^{\circ} \mathrm{C}$, a $\mathrm{RH}$ of $70 \%$ and a 12 -h photophase.

days) of the pupal stage of $C$. externa (7.4 days) reared at $25^{\circ} \mathrm{C}$ and fed $S$. graminum, is reported by Fonseca et al. (2001), and similar results were recorded by Núñez (1988).

Knowledge of the relation to temperature and prey in $C$. externa might be useful for deciding the release of this predator in natural environments. This is stressed by Angelini \& Freitas (2006).

Analyses using a quadratic equation to describe the effect of temperature on the duration of development of $C$. externa indicated an increase in the lower threshold temperature for the developement to the adult (Table 1). In a similar study but with Schizaphis graminum as prey and at temperatures ranging from $15^{\circ} \mathrm{C}$ to $30^{\circ} \mathrm{C}$ Maia et al. (2000) report LTT of $13.0^{\circ} \mathrm{C}$ for the first instar, which is higher than that reported for the same instar in the present study $\left(9.4^{\circ} \mathrm{C}\right)$ at the range of $12^{\circ} \mathrm{C}$ to $32^{\circ} \mathrm{C}$. However, for the other instars, their results are similar to ours.

Based on LTT of $10.7^{\circ} \mathrm{C}$ for development of the larval stage, 144.9 degree-days are necessary for $C$. externa to reach the adult stage.

\section{Survival of immature stages of Chrysoperla externa}

As temperature does not appear to affect this predator's survival during the first and second instars, the results for these instars were not analyzed. The average percentage survival of the first instar was 85.5, 83.3, 95.0, 83.3, 96.6 and $77.5 \%$ and $80.0,100.0,89.5,96.0,86.2$ and $93.5 \%$ in the second instar when reared at 12, 16, 20, 24, 28 and $32^{\circ} \mathrm{C}$, respectively.

However, the best fitting curves for the regression between temperature and the survival of development of the different stages (third instar, larval, pre-pupal and pupal stages) were obtained using quadratic polynomials. In the third instar temperature had a substantial effect on the survival. The highest percentage survival was recorded at $20^{\circ} \mathrm{C}$ to $28^{\circ} \mathrm{C}$ and the lowest at $12^{\circ} \mathrm{C}$ and $32^{\circ} \mathrm{C}$, so the results for the latter two temperatures were not included in the regression analysis. For the pupal stage, $24^{\circ} \mathrm{C}$ was the most favourable temperature for development (Fig. 2). Fonseca et al. (2001) also found that all the $C$. externa larvae fed $S$. graminum and kept at temperatures ranging from $24^{\circ} \mathrm{C}$ to $27^{\circ} \mathrm{C}$ survived, but very few survived at temperatures of $15^{\circ} \mathrm{C}$ and $30^{\circ} \mathrm{C}$.

The high survival of this species at temperatures ranging from $16^{\circ} \mathrm{C}$ to $28^{\circ} \mathrm{C}$ is similar to that reported by other authors, using similar temperatures, but different prey, such as $R$. maidis (Maia et al., 2004) and $S$. graminum (Fonseca et al., 2001). This suggests that $C$. externa can survive over a wide range of temperatures and feeding on different prey and might be an effective biological control agent.

\section{Predatory capacity of chrysopids}

The average daily and total consumption of aphids increased during larval development, with 3.9, 8.6, 70.5 and 38.0 aphids per day and totals of 10.0. 36.7, 478.9 and 525.5 aphids consumed in the first, second and third instars and over the whole larval stage, respectively (Fig. 3 ). There was nearly an 18 -fold increase in the average daily consumption and 48 fold increase in the average total consumption from the first to the third instar. The much higher consumption of prey in the third instar of $C$. externa is a general phenomenon in chrysopids and is also reported in studies in which this predator was fed Rhodobium porosum (Sanderson) (López, 1996), Cinara spp. (Cardoso \& Lazzari, 2003), R. maidis (Maia et al., 2004) and Hyadaphis foeniculi (Passerini) (Lira \& Batista, 2006) and regardless of the prey (Bortoli et al., 2006).

This also occurs in Chrysopa quadripunctata Burmeister and Chrysopa rufilabris Burmeister fed on Monellia caryella (Fitch) (Liao et al., 1985).

Fonseca et al. (2001), similarly report that the larvae of C. externa reared at $24^{\circ} \mathrm{C}$ and fed on S. graminum have an average daily consumption of $3.4,10.5$ and 76.7 aphids in the first, second and third instars, respectively. However, Lima (2004) report that third-instar larvae of $C$. externa consume only an average of 19.3 Brevicoryne brassicae nymphs, which is nearly a quarter of the number of $S$. flava consumed in this study. These differences in the number of aphids consumed might be related to the inherent characteristics of the aphid species eaten, such as size and suitability. B. brassicae is well known as unsuitable prey for aphid predators, because of its waxy cover (Hodek, 1996).

The total prey consumption in the first and second instars of $C$. externa is lower in the present paper than that reported by Ribeiro (1988) for this predator fed on Aphis gossypii at $25^{\circ} \mathrm{C}$. Also, the predatory capacity of the third instar recorded by this author is lower than that found in the present study and is in concert with the smaller prey consumption during the entire larval period. Burke \& Martin (1956), studying other lacewing species fed on A. gossypii, found that larvae of Chrysoperla oculata (Say), Chrysoperla plorabunda (Fitch) and Chrysoperla rufilabris consumed an average of 265, 208 and 268 aphids during the larval stage, respectively, roughly half the consumption recorded for C. externa in this study.

The difference in the consumption of aphids by $C$. externa reported in the literature is probably a conse- 
quence of rearing them on diet of different species of aphids, since some species of aphids can negatively affect a predator's larval development, as is reported by Canard (1973) for Chrysopa perla (Linnaeus) fed on different species of aphid.

The number of aphids consumed per predator reported here can be used to determine the number of $C$. externa larvae for release in programs aimed at controlling the abundance of $S$. flava. Although the third instar larvae are the most voracious releasing first instar larvae will minimize the cost of raising the predator in the laboratory.

\section{CONCLUSIONS}

C. externa can successfully complete its development when fed on $S$. flava and reared at temperatures ranging from $16^{\circ} \mathrm{C}$ to $28^{\circ} \mathrm{C}$, but not at $12^{\circ} \mathrm{C}$ and $32^{\circ} \mathrm{C}$. At $24^{\circ} \mathrm{C}$, the temperature at which $C$. externa performs best, its first, second and third instar larvae consumed on average 10,37 and 479 aphids, respectively.

ACKNOWLEDGEMENT. We thank Fundação de Amparo à Pesquisa do Estado de Minas Gerais for providing financial support.

\section{REFERENCES}

Angelini M.R. \& Freitas S. 2006: Efeito da escassez de alimento no desenvolvimento pós-embrionário e no potencial reprodutivo de Chrysoperla externa (Hagen) (Neuroptera: Chrysopidae) em laboratório. Bragantia 65: 129-137.

Blackman R.L. \& Eastop V.F. 2000: Aphids on the Worlds Crops: An Identification and Information Guide. 2nd ed. Wiley, Chicherster, $476 \mathrm{pp}$.

BEAN J.L. 1961: Predicting emergence of second-instar spruce budworm larvae from hibernation under field conditions in Minnesota. Ann. Entomol. Soc. Am. 54: 175-177.

Bortoli S.A., Caetano A.C., Murata A.T. \& Oliveira J.E.M. 2006: Desenvolvimento e capacidade predatória de Chrysoperla externa (Hagen) (Neuroptera: Chrysopidae) em diferentes presas. Rev. Biol. Ciênc. Terra 6: 145-152.

Burke H.R. \& MARTIN F. 1956: The biology of three chrysopid predators of the cotton aphid. J. Econ. Entomol. 49: 698-700.

CANARD M. 1973: Influence de l'alimentation sur le développement, la fecondité et la fertilité d'un prédateur aphidiphage: Chrysopa perla (L.) (Neuroptera, Chrysopidae). These (Docteur), Université Paul Sabatier de Toulouse, $175 \mathrm{pp}$.

CANARD M.S. \& PrincipI M.M. 1984: Life histories and behavior. In Canard M., Sémeria Y. \& New T.R. (eds): Biology of Chrysopidae. W. Junk, The Hague, pp. 92-100.

Cardoso J.T. \& Lazzari M.N. 2003: Development and consumption capacity of Chrysoperla externa (Hagen) (Neuroptera, Chrysopidae) fed with Cinara spp. (Hemiptera, Aphididae) under three temperatures. Rev. Bras. Zool. 20: 573-576.

Costa-Arbulú C., Gianoli E., González W.L. \& Niemeyer H.M. 2001: Feeding by the aphid Sipha flava produces a reddish spot on leaves of Sorghum halepense: An induced response? J. Chem. Ecol. 27: 271-281.

Figueira L.K., Lara F.M. \& CRUZI I. 2002: Efeito de genótipos de sorgo sobre o predador Chrysoperla externa (Hagen, 1861) (Neuroptera: Chrysopidae) alimentado com Schizaphis graminum (Rondani, 1852) (Hemiptera: Aphididae). Neotrop. Entomol. 31: 133-139.

Fonseca A.R., Carvalho C.F. \& Souza B. 2001: Capacidade predatória e aspectos biológicos das fases imaturas de Chrysoperla externa (Hagen, 1861) (Neuroptera: Chry- sopidae) alimentada com Schizaphis graminum (Rondani, 1852) (Hemiptera: Aphididae) em diferentes temperaturas. Ciênc. Agrotec. 25: 251-263.

Hodek I. 1996: Food relationships. In Hodek I. \& Honěk A. (eds): Ecology of Coccinellidae. Kluwer Academic Publishers Dordrecht, pp. 143-238.

Holman J. 1974: Los Afidos de Cuba. Instituto Cubano del Libro, La Habana, 304 pp.

KindLER S.D. \& DALRYMPLE R.L. 1999: Relative susceptibility of cereals and pasture grasses to the yellow sugarcane aphid (Homoptera: Aphididae). J. Agr. Urban. Entomol. 16: $13-122$.

Liao H.T., Harris M.K., Gilstrap F.E. \& Mansour F. 1985: Impact of natural enemies on the blackmargined pecan aphid, Monellia caryella (Homoptera: Aphididae). Environ. Entomol. 14: 122-126.

Lima A.K.V. DE O. 2004: Biologia e capacidade de predação de Chrysoperla externa Neuroptera: Chrysopidae) em Areia. Thesis, Center of agricultural sciences, Universidade Federal da Paraíba, Areia, PB, 90 pp.

Lira R.S. \& BAtista J.L. 2006: Aspectos biológicos de Chrysoperla externa alimentados com pulgões de erva-doce. Rev. Biol. Ciênc. Terra 6: 20-35.

LóPez C.C. 1996: Potencial de alimentação de Chrysoperla externa (Hagen, 1861) e Ceraeochrysa cincta (Schneider, 1851) (Neuroptera: Chrysopidae), sobre o pulgão da roseira Rhodobium porosum (Sanderson, 1900) (Hemiptera: Aphididae). M.S. Thesis, Universidade Estadual de São Paulo, 96 pp.

Maia W.J.M.S., Carvalho C.F. \& Souza B. 2000: Exigências térmicas de Chrysoperla externa (Hagen, 1861) (Neuroptera: Chrysopidae) alimentada com Schizaphis graminum (Rondani, 1852) (Hemiptera: Aphididae) em condições de laboratório. Ciênc. Agrotec. 24: 81-86.

Maia W.J.M.S., Carvalho C.F., Cruz I., Souza B. \& Maia T.J.A. 2004: Capacidade predatória e aspectos biológicos de Chrysoperla externa (Hagen, 1861) (Neuroptera: Chrysopidae) alimentada com Rhopalosiphum maidis (Fitch, 1856) (Hemiptera: Aphididae). Ciênc. Agrotec. 28: 1259-1268.

Medina-Gaud S., Martorell L.F. \& Robles R.B. 1965: Notes on the biology and control of the yellow aphid of sugarcane, Sipha flava (Forbes) in Puerto Rico. In: Proceedings of the 12th Congress of the International Society of Sugarcane Technologists, San Juan, Puerto Rico, March 28 - April 10. pp. 1307-1320.

Murata A.T., Caetano A.C., Bortoli S.A. \& Brito C.H. 2006: Capacidade de consumo de Chrysoperla externa (Hagen, 1861) (Neuroptera: Chrysopidae) em diferentes presas. Rev. Caatinga 19: 304-309.

NúÑEZ Z.E. 1988: Ciclo biológico y crianza de Chrysoperla externa y Ceraeochrysa cincta (Neuroptera: Chrysopidae). Rev. Per. Entomol. 31: 76-82.

Oliveira S.A., Souza B., Auad A.M., Silva D.M., Souza L.S. \& Carvalho C.A. 2009: Desenvolvimento e reprodução de Sipha flava (Forbes) (Hemiptera: Aphididae) em diferentes temperaturas. Neotrop. Entomol. 38: 70-76.

Ribeiro M.J. 1988: Biologia de Chrysoperla externa (Hagen, 1861) (Neuroptera: Chrysopidae) alimentada com diferentes dietas. M.S. Thesis, Universidade Federal de Lavras, 131 pp.

SAmson P.R. \& BLood P.R.B. 1979: Biology and temperature relationships of Chrysopa sp., Micromus tasmaniae and Nabis capsiformis. Entomol. Exp. Appl. 25: 253-259.

Silva A.R., Reis P.R., Souza B., Carvalho C.F., Carvalho G.A. \& Cosme V.L. 2006: Flutuação populacional de adultos de Chrysoperla externa (Hagen, 1861) (Neuroptera: Chrysopi- 
dae) em cafeeiros conduzidos em sistemas orgânico e convencional. Man. Integr. Plagas 77: 44-49.

Sмith R.C. 1922: A study of the biology of the Chrysopidae. Ann. Entomol. Soc. Am. 14: 27-35.
Webster J.A. 1990: Yellow sugarcane aphid (Homoptera: Aphididae): Detection and mechanisms of resistance among Ethiopian sorghum lines. J. Econ. Entomol. 83: 1053-1057.

Received September 7, 2009; revised and accepted November 24, 2009 